\title{
Karakterisasi dan Uji Stabilitas Digestif Nanoemulsi $\beta$-Karoten yang Dibuat dengan Metode Emulsifikasi Spontan
}

\author{
Characterization and Digestive Stability Evaluation of $\beta$-Carotene Nanoemulsions Prepared by \\ Spontaneous Emulsification Method
}

\author{
Setyaningrum Ariviani ${ }^{1 *}$, Windi Atmaka1, Sri Raharjo² \\ ${ }^{1}$ Program studi Ilmu dan Teknologi Pangan, Fakultas Pertanian, Universitas Sebelas Maret, \\ Jl. Ir. Sutami No. 36A, Kentingan, Surakarta 57126, Indonesia \\ ${ }^{2}$ Departemen Teknologi Pangan dan Hasil Pertanian, Fakultas Teknologi Pertanian, Universitas Gadjah Mada, Jl. \\ Flora No. 1, Bulaksumur, Yogyakarta 55281, Indonesia \\ *Email: setya_ariviani@yahoo.com
}

Submisi: 18 Oktober 2017; Penerimaan: 11 Januari 2018

\begin{abstract}
ABSTRAK
$\beta$-Karoten mempunyai berbagai manfaat kesehatan, namun aplikasinya dalam formulasi pangan sangat terbatas karena tidak stabil dan mudah mengalami degradasi. Stabilitas $\beta$-karoten dapat ditingkatkan dengan menggabungkannya dalam sistem penghantaran berbasis emulsi minyak dalam air $(\mathrm{o} / \mathrm{w})$. Penelitian ini bertujuan untuk melakukan karakterisasi nanoemulsi $\beta$-karoten yang dibuat dengan metode emulsifikasi spontan menggunakan kombinasi tiga surfaktan food grade (Tween 80, Span 40, Span 80), minyak sawit maupun VCO (virgin coconut oil) sebagai fase minyak dengan rasio surfaktan-fase minyak 4.. Penelitian ini juga mengkaji stabilitas fisikokimiawi nanoemulsi $\beta$-karoten selama pencernaan di mulut, lambung dan usus dengan menggunakan model digesti in vitro. Hasil penelitian memperlihatkan bahwa nanoemulsi $\beta$-karoten yang dibuat dengan fase minyak VCO maupun minyak sawit memiliki pH netral $(6,8 \pm 0,1)$, rerata diameter partikel $129-159 \mathrm{~nm}$, distribusi ukuran partikel monomodal dengan nilai indeks polidispersitas (polydispersity index, PdI) rendah $(0,214-0,266)$ dan zeta potensial yang tidak berbeda nyata $([-6,59]-[-8,9])$. Nanoemulsi $\beta$-karoten dengan fase minyak VCO memiliki rerata diameter partikel yang lebih kecil dibanding minyak sawit sebagai fase minyak. Jenis fase minyak tidak berpengaruh terhadap stabilitas fisik nanoemulsi $\beta$-karoten selama simulasi pencernaan di mulut, lambung maupun usus. Nanoemulsi $\beta$-karoten dengan fase minyak VCO maupun minyak sawit stabil terhadap pencernaan di mulut maupun lambung. Setelah melewati fase usus, terjadi peningkatan diameter partikel rerata dan perubahan distribusi ukuran partikel dari monomodal menjadi bimodal. Retensi $\beta$-karoten dalam nanoemulsi VCO setelah melewati simulasi pencernaan mulut, lambung dilanjutkan fase usus tidak berbeda nyata dengan retensi $\beta$-karoten dalam nanoemulsi minyak sawit.
\end{abstract}

Kata kunci: Nanoemulsi; stabilitas fisikokimia; simulasi pencernaan; $\beta$-karoten

\begin{abstract}
$\beta$-Carotene exhibits a wide range of health benefits, but its application in food formulation is very limited because of its instability and susceptibility to degradation. The stability of $\beta$-carotene can be improved by incorporation into an oil-in-water $(\mathrm{o} / \mathrm{w})$ emulsions. The objective of this research was to characterize $\beta$-carotene loaded nanoemulsions prepared with spontaneous emulsification method using ternary food-grade surfactants (Tween 80, Span 40, Span 80 ) and palm oil or VCO (virgin coconut oil) as oil phase with the surfactant-oil ratio of 4 . The physicochemical stability of $\beta$-carotene loaded nanoemulsions during simulated digestions, which consist of the mouth, stomach, and intestine phases, was also evaluated using in-vitro digestion model. The results showed that $\beta$-carotene loaded nanoemulsions, prepared either using VCO or palm oil as the oil phase, had neutral pH (6.8 0.1$)$, mean particle diameter of $129-159 \mathrm{~nm}$, showed monomodal particle size distribution with low polydispersity index (PdI) values $(0.214-0.266)$, and were not significantly different in zeta potential values $([-6,59]-[-8,9])$. The $\beta$-carotene loaded nanoemulsions with VCO as the oil phase had a smaller mean particle diameter than that of palm oil. The physical stability of the $\beta$-carotene loaded nanoemulsions against digestive simulation in the mouth, stomach or intestine phases was not influenced by the oil phase type. Both nanoemulsions were stable against simulated digestion in the mouth and stomach phases. After passing through the intestinal phase, the mean particle diameter increased and
\end{abstract}


the particle size distribution changed from monomodal to bimodal. The $\beta$-carotene retention after passing through the mouth, stomach and intestinal phases of the $\beta$-carotene loaded nanoemulsion prepared using VCO were not significantly different from the palm oil.

Keywords: Nanoemulsions; physicochemical stability; simulated digestion; $\beta$-carotene

\section{PENDAHULUAN}

Tubuh tidak dapat mensintesis karotenoid, oleh sebab itu kebutuhan karotenoid mutlak dipenuhi dari asupan. Karotenoid merupakan salah satu kelompok mikronutrien utama pada diet manusia (RodriguezAmaya dkk., 2008). ß-Karoten sebagai salah satu komponen karotenoid, memiliki beberapa kelebihan dibanding karotenoid yang lain. $\beta$-Karoten memiliki aktivitas provitamin A dan biokonversi tertinggi (Castenmiller dan West 1998; Tan dan Nakajima 2005; Donhowe dan Kong 2014). $\beta$-Karoten merupakan karotenoid utama dalam diet, jaringan dan plasma manusia (Krinsky dan Johnson, 2005). $\beta$-Karoten mempunyai aktivitas anti-inflammasi (Bai dkk., 2005) dan antikanker (Gloria dkk., 2014). Boon dkk. (2010) menjelaskan bahwa rantai poliena terkonjugasi yang merupakan ciri khas dari karotenoid mengakibatkan senyawa ini rentan terhadap degradasi. Degradasi karotenoid menyebabkan warnanya memudar dan menurunkan peranannya bagi kesehatan.

Courraud dkk. (2013) meneliti tentang stabilitas beberapa karotenoid dan vitamin A selama digesti invitro. $\beta$-Karoten mengalami kerusakan dan terjadi penurunan $69 \%$ yaitu tersisa $52 \%$ setelah melewati fase lambung dan $31 \%$ setelah melewati usus halus Menurut McClements dan Li (2010) dan McClements (2010), salah satu strategi yang efektif untuk proteksi dan enkapsulasi komponen bioaktif yang tidak larut air seperti $\beta$-karoten adalah dengan membawanya dalam sistem penghantaran berbasis emulsi.

Qian dkk. (2012a) dan Yi dkk. (2014) memperlihatkan bahwa sistem penghantaran emulsi maupun nanoemulsi mampu meningkatkan stabilitas $\beta$ karoten selama digesti in-vitro. Pada kedua penelitian tersebut sistem penghantaran dibuat dengan melibatkan energi tinggi, yaitu homogenisasi tekanan tinggi. Nanoemulsi umumnya dibuat dengan melibatkan energi tinggi untuk membentuk droplet submikron dan meningkatkan luas daerah antarmuka air/minyak, dengan menggunakan perangkat tertentu seperti generator ultrasonik atau homogenizer tekanan tinggi (Anton dan Vandamme, 2011). Nanoemulsi dapat dibuat tanpa melibatkan energi tinggi atau menggunakan energi rendah, yaitu dengan emulsifikasi spontan maupun fase inverse (Anton dan Vandamme 2011; Yang dkk., 2012). Namun pada pembuatan nanoemulsi dengan energi rendah memerlukan surfaktan dalam jumlah yang lebih banyak, dengan demikian memerlukan rasio surfaktan minyak yang lebih tinggi (Yang dkk., 2012; Rao dan McClements 2011).
Menurut Nik dkk. (2010), sifat sistem emulsi sebagai pembawa molekul bioaktif lipofilik seperti karotenoid selama transit melalui saluran pencernaan sangat berpengaruh terhadap perilaku molekul bioaktif yang dibawanya. Laju degradasi $\beta$-karoten dalam sistem pembawa minyak dalam air (o/w) sangat dipengaruhi oleh stabilitas sistem pembawanya, laju degradasi $\beta$-karoten semakin rendah pada sistem pembawa yang lebih stabil (Cornacchia dan Roos, 2011). Emulsi maupun nanoemulsi $\beta$-karoten mengalami destabilisasi yang ditandai dengan perubahan rerata diameter partikel droplet, distribusi ukuran maupun zeta potensialnya selama simulasi digesti in vitro. Destabiliasi fisik dipengaruhi oleh jenis surfaktan (Liu dkk., 2012), ukuran diameter dropet (Salvia-Trujillo dkk., 2013a) dan jenis minyak (Qian dkk., 2012a).

Penelitian ini bertujuan untuk melakukan karakterisasi nanoemulsi sebagai sistem penghantaran $\beta$-karoten yang dibuat dengan kombinasi tiga surfaktan food grade, minyak sawit maupun VCO sebagai fase minyak, menggunakan metode emulsifikasi spontan. VCO maupun minyak sawit merupakan dua jenis minyak tropis yang umum dikonsumsi di Indonesia. VCO merupakan minyak dengan trigliserida dominan rantai medium, sedangkan minyak sawit memiliki trigliserida dominan rantai panjang (Mu dan Høy, 2004). Stabilitas fisik dan kimiwi nanoemulsi $\beta$-karoten selama simulasi pencernaan mulut, lambung dan usus juga ditentukan.

\section{METODE PENELITIAN}

\section{Bahan}

ß-karoten (Type I, C9750), Span 20 (sorbitan monolaurat), Span 40 (sorbitan monopalmitat), dan Span 80 (sorbitan monooleat) diperoleh dari SigmaAldrich Co. (St. Louis, MO, AS). Disodium hydrogen phosphate dehydrate, Tween 80 (Polyoxyethylene sorbitan monooleate), dan sodium dihydrogen phosphate monohydrate didapatkan dari Merck Milipore Co. (Darmstadt, Jerman). VCO (virgin coconut oil) dan minyak kelapa sawit berasal dari pasar lokal dan digunakan tanpa pemurnian. Reagensia untuk digesti in vitro: bahan anorganik, glukosa dan urea dari Merck Millipore Co. (Darmstadt, Jerman), bahan-bahan yang lain yaitu enzim a-amilase, pepsin, lipase, pankreatin, bovine serum albumin (BSA), empedu, mucin, asam urat, glukosamin hidroklorida dan asam glukoronat dari Sigma-Aldrich Co. (St. Louis, MO, AS). Klorofom dari Merck Millipore Co. (Darmstadt, Jerman). 


\section{Alat}

Alat yang digunakan meliputi heating magnetic stirer (AREC-VELP Scientifica), neraca analitik (AUX 220, Shimadzu, Jepang), water bath shaker (SWB-20, Haake, Jerman), spektrofotometer Uv-vis (Shimadzu Uv 1650 pc), Zetasizer Nano ZS (Malvern), pH meter (Schott), sentrifuse (Backman J-6B, Soma Technology Inc. AS).

\section{Pembuatan Nanoemulsi $\beta$-karoten}

Nanoemulsi $\beta$-karoten dibuat menggunakan kombinasi surfaktan non ionik yang memiliki hydrophile lipophile balance (HLB) rendah, sedang dan tinggi, yaitu Span 80, Span 40, dan Tween 80. Nanoemulsi dibuat dengan metode emulsifikasi spontan menggunakan VCO maupun minyak sawit sebagai fase minyak, dengan rasio surfaktan- fase minyak 4 dan sebagai fase aquoeus digunakan buffer fosfat $\mathrm{pH}$ 7,0 (10mM) (Ariviani dkk., 2015). Cara pembuatan nanoemulsi $\beta$-karoten dengan menambahkan $\beta$-karoten $(0,025 \% \quad b / b)$ ke dalam campuran surfaktan-minyak, diaduk dan dipanaskan menggunakan hotplate magnetic stirrer suhu $70^{\circ} \mathrm{C}$. Setelah 10 menit, ditambahkan fase aqueous yang telah dicampur dengan $1 / 4$ atau $1 / 2$ bagian surfaktan HLB tinggi sambil terus diaduk dan dipanaskan hingga total waktu 20 menit. Selanjutnya diinkubasi pada suhu ruang selama 24 jam.

\section{Karakterisasi Nanoemulsi $\boldsymbol{\beta}$-karoten}

Nanoemulsi $\beta$-karoten dikarakterisasi dengan pengukuran $\mathrm{pH}$, ukuran dan distribusi ukuran partikel serta zeta potensialnya. $\mathrm{pH}$ ditentukan menggunakan $\mathrm{pH}$ meter Schott pada suhu ruang $\left(27 \pm 2{ }^{\circ} \mathrm{C}\right)$, dikalibrasi dengan bufer standar $\mathrm{pH}$ 7. Distribusi ukuran partikel dan rerata ukuran partikel nanoemulsi ditentukan dengan dynamic light scattering (DLS) pada panjang gelombang $633 \mathrm{~nm}$ dan suhu $25^{\circ} \mathrm{C}$. Zeta potensial partikel diukur dengan phase-analysis light scattering (PLS) menggunakan Zeta dip cell (Salvia-Trujillo dkk. 2013b). Sampel diencerkan dengan $10 \mathrm{mM}$ bufer fosfat
pH 7 sebelum analisis, untuk menghindari multiplescatering effects selama pengujian.

\section{Stabilitas Fisik dan Stabilitas Kimawi Nanoemulsi $\beta$-karoten Selama Simulasi Digesti in Vitro}

Stabilitas fisik ditentukan dengan pengukuran rerata diameter partikel droplet, distribusi ukuran partikel droplet dan zeta potensialnya pada nanoemulsi $\beta$ karoten awal, setelah dipapar fase mulut, fase lambung dan fase usus (Qian dkk. 2012a; Salvia-Trujillo dkk. 2013a). Model digesti in vitro yang digunakan dalam penelitian ini mengikuti metode Hur dkk. (2011) dan Kabak dan Ozbey (2012) dengan sedikit modifikasi. Tiap-tiap sistem penghantaran $\beta$-karoten dilewatkan melalui tiga tahap simulasi pencernaan yang terdiri dari fase mulut, lambung dan usus. Komposisi cairan saliva, lambung, duodenum dan empedu seperti pada Tabel 1 . Fase mulut disimulasi dengan menambahkan $6 \mathrm{~mL}$ nanoemulsi $\beta$-karoten pada $6 \mathrm{ml}$ cairan simulasi saliva. Campuran tersebut selanjutnya diinkubasi dalam water bath shaker (SWB-20, Haake, Germany) selama 10 menit pada suhu $37^{\circ} \mathrm{C}$ dengan kecepatan $100 \mathrm{rpm}$. Digesta dari fase mulut selanjutnya dicampur dengan $12 \mathrm{~mL}$ cairan simulasi lambung sambil terus digojog dalam water bath shaker suhu $37^{\circ} \mathrm{C}$ dengan kecepatan $100 \mathrm{rpm}$ selama 2 jam, untuk mensimulasikan fase lambung. Fase usus disimulasikan dengan mencampurkan digesta dari fase lambung dengan 12 $\mathrm{mL}$ cairan simulasi duodenum, $6 \mathrm{~mL}$ cairan simulasi empedu, $2 \mathrm{~mL}$ larutan bikarbonat (1M), sambil terus digojog pada suhu $37^{\circ} \mathrm{C}$ dengan kecepatan $100 \mathrm{rpm}$ selama 2 jam.

Stabilitas kimiawi $\beta$-karoten dalam nanoemulsi selama simulasi digesti in-vitro ditentukan dengan pengukuran kadar $\beta$-karoten dengan metode UVvisible spectroscopy (Qian dkk. 2012b) pada awal, setelah dipapar fase mulut, lambung dan usus. Kadar $\beta$-karoten dalam sampel ditentukan dengan ekstraksi $\beta$-karoten menggunakan klorofom $(1: 2 \mathrm{v} / \mathrm{v})$, divortex

Tabel 1 . Komponen penyusun cairan pencernaan (digestive fluid)

\begin{tabular}{|c|c|c|c|c|}
\hline Komponen & Saliva & Gastric juice & Duodenal juice & Bile juice \\
\hline $\begin{array}{l}\text { Bahan } \\
\text { anorganik }\end{array}$ & $\begin{array}{l}10 \mathrm{~mL} \mathrm{KCl} 89.6 \mathrm{~g} / \mathrm{L} \\
10 \mathrm{~mL} \mathrm{KSCN} 20 \mathrm{~g} / \mathrm{L} \\
10 \mathrm{~mL} \mathrm{NaH} \mathrm{PO}_{4} 88,8 \mathrm{~g} / \mathrm{L} \\
10 \mathrm{~mL} \mathrm{NaSO} 47 \mathrm{~g} / \mathrm{L} \\
1,7 \mathrm{~mL} \mathrm{NaCl} \mathrm{175,3} \mathrm{g/L} \\
20 \mathrm{~mL} \mathrm{NaHCO}{ }_{3} 84,7 \mathrm{~g} / \mathrm{L}\end{array}$ & 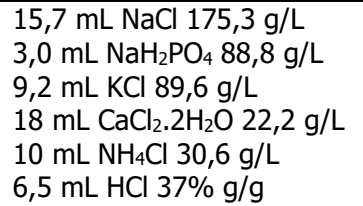 & $\begin{array}{l}40 \mathrm{~mL} \mathrm{NaCl} \mathrm{175,3} \mathrm{g/L} \\
40 \mathrm{~mL} \mathrm{NaHCO} 84,7 \mathrm{~g} / \mathrm{L} \\
10 \mathrm{~mL} \mathrm{KH} \mathrm{PO}_{4} 8 \mathrm{~g} / \mathrm{L} \\
6,3 \mathrm{~mL} \mathrm{KCl} \mathrm{89,6} \mathrm{g/L} \\
10 \mathrm{~mL} \mathrm{MgCl} 5 \mathrm{~g} / \mathrm{L} \\
180 \mu \mathrm{HCl} \mathrm{37 \%} \mathrm{g/g}\end{array}$ & $\begin{array}{l}30 \mathrm{~mL} \mathrm{NaCl} 175,3 \mathrm{~g} / \mathrm{L} \\
68,3 \mathrm{~mL} \mathrm{NaHCO} 384,7 \mathrm{~g} / \mathrm{L} \\
4,2 \mathrm{~mL} \mathrm{KCl} 89,6 \mathrm{~g} / \mathrm{L} \\
150 \mu \mathrm{HCl} 37 \% \mathrm{~g} / \mathrm{g} \\
10 \mathrm{~mL} \text { urea } 25 \mathrm{~g} / \mathrm{L}\end{array}$ \\
\hline Bahan organik & $8 \mathrm{~mL}$ urea $25 \mathrm{~g} / \mathrm{L}$ & $\begin{array}{l}10 \mathrm{~mL} \text { glucose } 65 \mathrm{~g} / \mathrm{L} \\
10 \mathrm{~mL} \text { glucuronic acid } 2 \mathrm{~g} / \mathrm{L} \\
3,4 \mathrm{~mL} \text { urea } 25 \mathrm{~g} / \mathrm{L} \\
10 \mathrm{~mL} \text { glucosamine } \\
\text { hydrochloride } 33 \mathrm{~g} / \mathrm{L}\end{array}$ & $4 \mathrm{~mL}$ urea $25 \mathrm{~g} / \mathrm{L}$ & \\
\hline $\begin{array}{l}\text { Bahan lain } \\
\text { yang } \\
\text { ditambahkan }\end{array}$ & $\begin{array}{l}290 \mathrm{mg} \text { a-Amylase } \\
2.5 \mathrm{~g} \text { Pepsin } \\
25 \mathrm{mg} \text { Mucin }\end{array}$ & $\begin{array}{l}1 \mathrm{~g} \mathrm{BSA} \\
15 \mathrm{mg} \text { Uric acid } \\
3 \mathrm{~g} \text { Mucin }\end{array}$ & $\begin{array}{l}9 \mathrm{~mL} \mathrm{CaCl} 2.2 \mathrm{H}_{2} \mathrm{O} 22.2 \mathrm{~g} / \mathrm{L} \\
1 \mathrm{~g} \mathrm{BSA} \\
9 \mathrm{~g} \text { Pankreatin } \\
1,5 \mathrm{~g} \text { Lipase }\end{array}$ & $\begin{array}{l}10 \mathrm{~mL} \mathrm{CaCl} 2 \cdot 2 \mathrm{H}_{2} \mathrm{O} 22,2 \mathrm{~g} / \mathrm{L} \\
1,8 \mathrm{~g} \mathrm{BSA} \\
30 \mathrm{~g} \text { empedu }\end{array}$ \\
\hline
\end{tabular}


dan disentrifugasi pada $2923 \mathrm{~g}$, suhu $4{ }^{\circ} \mathrm{C}$ selama 15 menit. Fase klorofom yang mengandung $\beta$-karoten dipisahkan dan diukur absorbansinya pada panjang gelombang $464 \mathrm{~nm}$ ( $\lambda$ maks) menggunakan spektrofotometer uv-vis. Klorofom murni digunakan sebagai blanko. Kadar $\beta$-karoten dalam sampel dikuantifikasi dengan kurva standar $\beta$-karoten pada konsentrasi 0-20 ppm. Stabilitas kimiawi $\beta$-karoten dalam sistem penghantaran nanoemulsi dinyatakan sebagai retensi $\beta$-karoten $(\%)=100 \times(\mathrm{CO} / \mathrm{Ct})$, dimana C0 adalah konsentrasi $\beta$-karoten awal, Ct adalah konsentrasi beta-karoten pada tiap fase digesti.

\section{Analisis Data}

Keseluruhan pengukuran dilakukan minimal tiga kali ulangan sampel dan dilaporkan sebagai rerata dan standar deviasinya. Data dianalisis menggunakan program IBM SPSS Statistics 22 (SPSS Inc., Chicago, USA) dengan analysis of variance (ANOVA). Apabila berbeda nyata $(p<0,05)$ dilanjutkan dengan Duncan's multiple range test (DMRT).

\section{HASIL DAN PEMBAHASAN}

\section{Karakteristik Nanoemulsi $\boldsymbol{\beta}$-karoten}

Nilai pH sistem pembawa berbasis emulsi memiliki dampak yang signifikan terhadap stabilitas karotenoid yang dibawanya. Nanoemulsi $\beta$-karoten dengan fase minyak VCO maupun minyak sawit yang dibuat memiliki $\mathrm{pH}$ netral $(6,8 \pm 0,1)$. pH netral tersebut diharapkan akan memberikan efek perlindungan yang optimum pada $\beta$ karoten yang dibawanya. Penelitian Boon (2009), Qian dkk. (2012b) dan Xu dkk. (2013), memperlihatkan bahwa degradasi karotenoid jauh lebih cepat pada emulsi maupun nanoemulsi dengan $\mathrm{pH} 4$ dan dibawahnya dibanding $\mathrm{pH} 7$.

Nanoemulsi dapat dibedakan dari sistem pembawa berbasis emulsi yang lain berdasarkan ukuran kenampakan, stabilitas, dan ukuran partikel droplet fase terdispersinya. Nanoemulsi bersifat kinetically stable, kenampakannya transparan atau sedikit keruh, dan memiliki ukuran partikel droplet 20-200 nm. Meskipun emulsi konvensional juga bersifat kinetically stable, namun memiliki. kenampakan keruh dan tidak tembus cahaya serta ukuran partikel droplet $0,2-10 \mu \mathrm{m}$. Mikroemulsi bersifat thermodinamically stable, transparan, dan memiliki ukuran partikel droplet 5-100 $\mathrm{nm}$ (Anton dan Vandame, 2011; Flanagan dan Singh, 2006; Mason dkk., 2006; McClements, 2012; McClements dan Rao, 2011). Oleh karena itu, karakterisasi nanoemulsi $\beta$-karoten dalam penelitian ini juga dilakukan dengan penentuan rerata dan distribusi ukuran partikel serta zeta potensialnya. Hasilnya disajikan pada Gambar 1. Parameter zeta potensial memberikan gambaran tentang stabilitas sistem emulsi terkait dengan tolakan listrik dropletnya (Heurtault dkk., 2003).
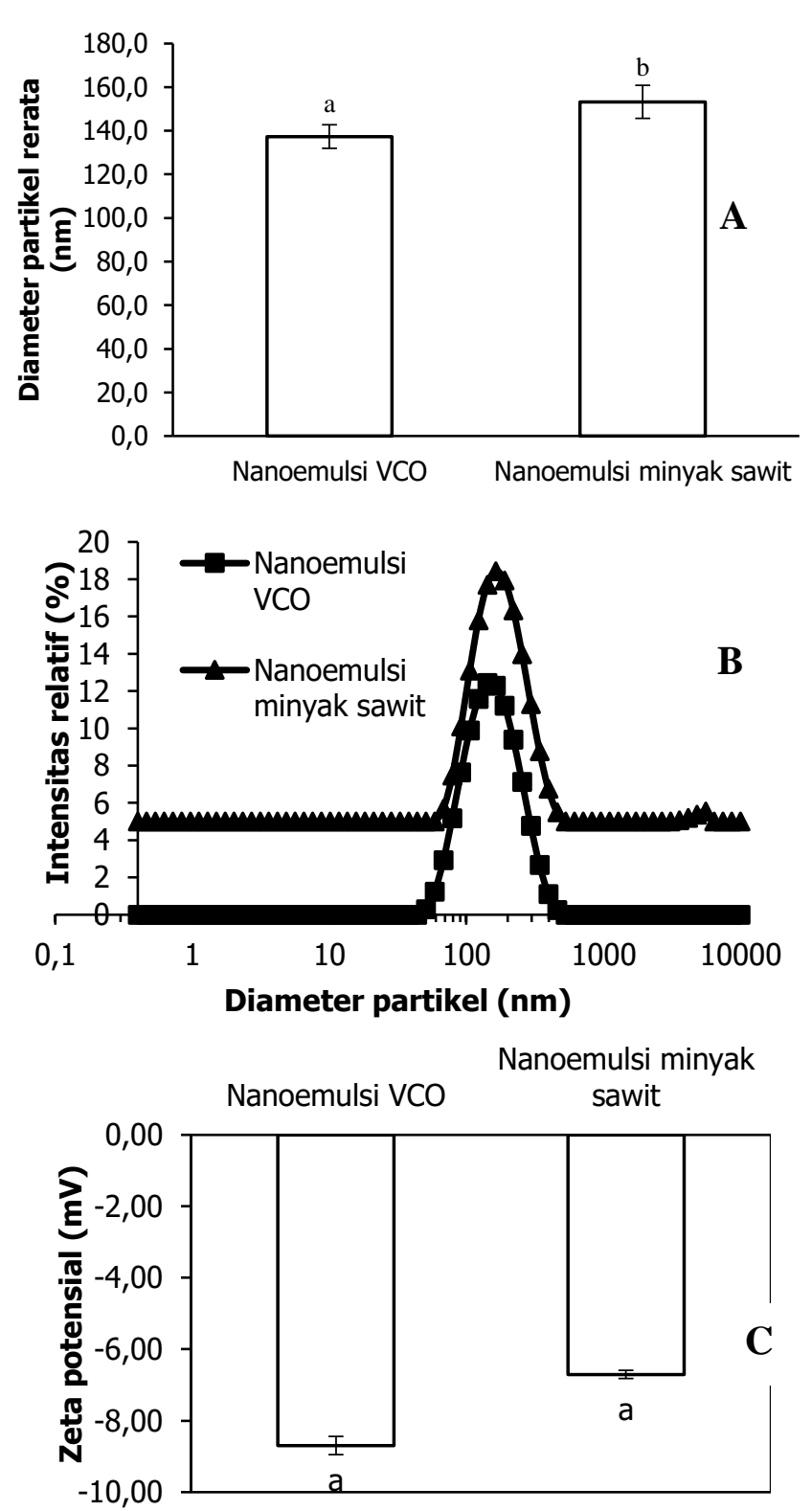

Gambar 1. Diameter partikel rerata (A), distribusi ukuran partikel (B) dan zeta potensial (C) nanoemulsi $\beta$-karoten dengan fase minyak VCO maupun minyak sawit. Notasi yang berbeda menunjukkan berbeda nyata $(p<0,05)$

Gambar 1A mengindikasikan bahwa nanoemulsi VCO memiliki diameter partikel rerata $129-159 \mathrm{~nm}$ yang nsesuai dengan karakteristik ukuran nanoemulsi. Jenis minyak berpengaruh terhadap diameter partikel rerata nanoemulsi $\beta$-karoten. Minyak sawit menghasilkan nanoemulsi $\beta$-karoten dengan ukuran partikel rerata yang signifikan lebih tinggi dibandingkan dengan VCO. Salvia-Trujillo dkk. (2013c) melaporkan bahwa jenis fase minyak berpengaruh terhadap karakteristik diameter partikel droplet nanoemulsi $\beta$ karoten. Nanoemulsi $\beta$-karoten dengan fase minyak trigliserida rantai panjang (long chain triglycerides, LCT) memiliki rerata diameter droplet yang lebih besar dibanding trigliserida rantai medium (medium chain triglycerides, MCT). Hasil penelitian ini sejalan dengan penelitian Yang dan McClements (2013) yang menunjukkan bahwa emulsi dengan fase minyak MCT 
memiliki diameter partikel rerata yang signifikan lebih kecil dibanding emulsi dengan fase minyak LCT $(p<$ $0,1)$. VCO merupakan trigliserida dengan asam lemak dominan berantai sedang, yaitu 5,21\% kaprat, 48,66\% laurat, dan 17,82\% miristat (Dayrit dkk., 2007). Asam lemak penyusun minyak sawit sebagian besar merupakan asam lemak rantai panjang, seperti palmitat (C16:0) (36,7\%), stearat (C18:0) $(6,6 \%)$, oleat (C18:1) $(46,1 \%)$, linoleat (C18:2) (8,6\%) (Ramos dkk., 2009).

Nanoemulsi $\beta$-karoten memiliki distribusi ukuran partikel monomodal. Hasil ini mengindikasikan bahwa nanoemulsi $\beta$-karoten memiliki ukuran partikel droplet yang relatif homogen. Hal ini juga didukung dengan nilai indeks polidispersitas (polydispersity index, PdI) yang rendah, yaitu 0,223 $\pm 0,008$ untuk nanoemulsi VCO dan $0,255 \pm 0,011$ untuk nanoemulsi minyak sawit. PdI mengukur penyebaran distribusi ukuran partikel. Nilai PdI dari 0 sampai 1 , jika nilainya mendekati 1 mengindikasikan distribusi ukuran partikel yang heterogen dan sebaliknya (Salvia-Trujillo dkk., 2013d). Nilai PdI yang rendah menunjukkan distribusi ukuran partikel yang sempit (Yuan dkk., 2008).

Hasil analisis zeta potensial (Gambar 1C) menunjukkan bahwa meskipun keseluruhan surfaktan yang digunakan merupakan surfaktan nonionik, namun nanoemulsi $\beta$-karoten yang dihasilkan memiliki muatan listrik partikel negatif (-). Hal ini dimungkinkan karena adsorpsi ion $\mathrm{OH}$ - dari fase aqueous atau adanya impuritis anionik (seperti asam lemak bebas) dalam surfaktan atau minyak yang digunakan untuk mempersiapkan emulsi (McClements, 2005). Beberapa penelitian sebelumnya seperti Qian dkk. (2012a), SalviaTrujillo dkk. (2013a; 2013c) dan Mao dkk. (2009) yang menggunakan surfaktan nonionik Tween 20 untuk menstabilkan nanoemulsi $\beta$-karoten, juga memperlihatkan nilai zeta potensial negatif. Hsu dan Nacu (2003), menyatakan bahwa surfaktan nonionik mampu membentuk ikatan hidrogen dengan ion $\mathrm{OH}^{-}$.

\section{Stabilitas Fisik Nanoemulsi $\beta$-karoten Selama Simulasi Pencernaan in-vitro}

Nik dkk. (2010), menyatakan bahwa perilaku molekul bioaktif dalam sistem emulsi sangat dipengaruhi oleh sifat sistem emulsi yang membawanya selama melewati saluran pencernaan. Selama pencernaan, droplet emulsi lipid mengalami satu seri proses fisik dan biokimiawi yang dapat mengakibatkan destabilisasi emulsi (Sarkar dkk., 2010). Oleh sebab itu, penting untuk mempelajari stabilitas fisik mikroemulsi maupun nanoemulsi sebagai pembawa $\beta$-karoten.

Pada penelitian ini digunakan 2 sampel nanoemulsi dengan konsentrasi $\beta$-karoten yang sama, dan jenis minyak yang berbeda. Kinetika degradasi $\beta$-karoten dipengaruhi oleh konsentrasi awalnya (Stevanovich dan Karel, 1982). Stabilitas sistem dispersi sebagai pembawa $\beta$-karoten selama digesti in vitro dipengaruhi oleh jenis fase minyak (Qian dkk., 2012a).

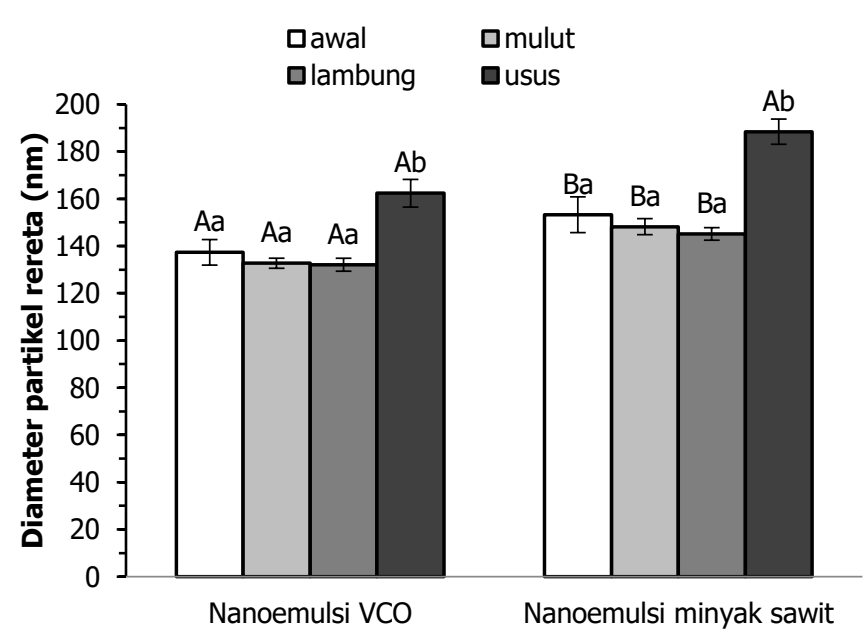

Gambar 2. Diameter partikel rerata nanoemulsi $\beta$-karoten dengan fase minyak VCO dan minyak sawit, selama simulasi pencernaan. Huruf kapital yang berbeda menunjukkan berbeda nyata $(p<0,05)$ pada fase digesti yang sama, huruf kecil yang berbeda menunjukkan berbeda nyata $(p<0,05)$ pada sistem penghantaran yang sama
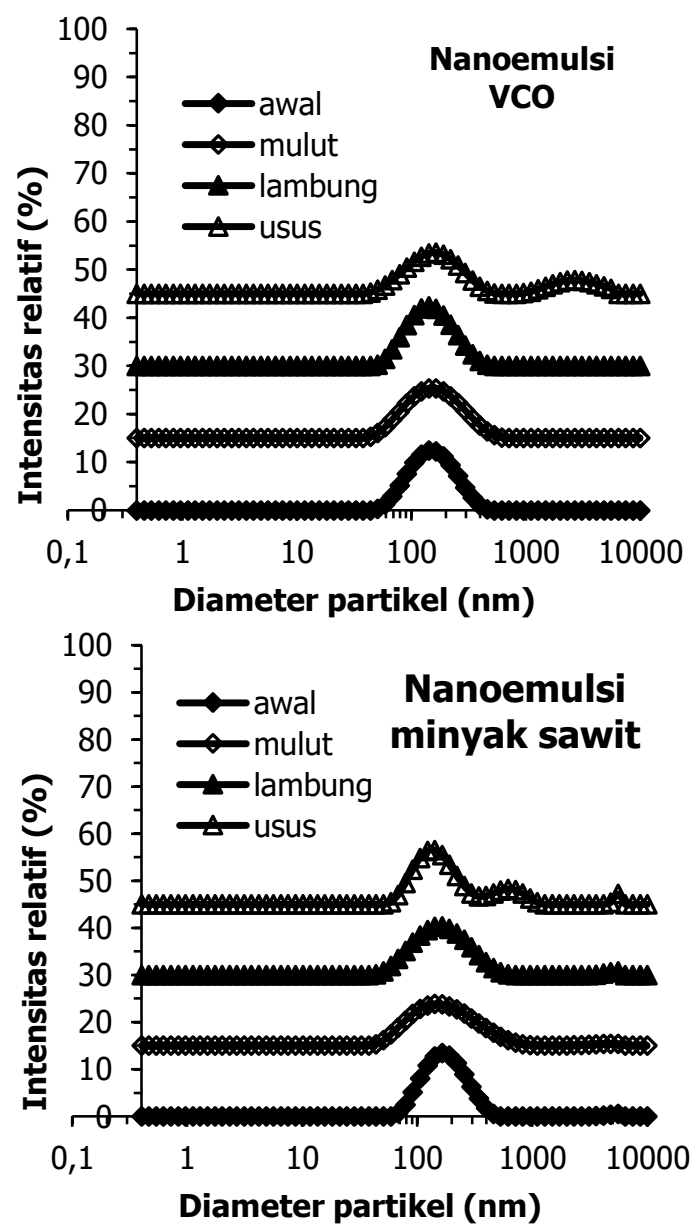

Gambar 3. Distribusi ukuran partikel nanoemulsi $\beta$-karoten yang dibuat dengan fase minyak VCO dan minyak sawit selama simulasi pencernaan

Beberapa peneliti seperti Liu dkk. (2012), Qian dkk. (2012a), Salvia-Trujillo dkk. (2013a) dan Mun dkk. 
(2015) telah mempelajari stabilitas emulsi maupun nanoemulsi sebagai sistem pembawa $\beta$-karoten selama simulasi digesti in-vitro. Uji Stabilitas sistem pembawa berbasis emulsi dapat ditentukan dengan evaluasi stabilitas fisik, melalui pengukuran perubahan ukuran dan distribusi ukuran partikel, serta zeta potensial partikel droplet setelah dipapar fase mulut, lambung maupun usus. Perubahan diameter rerata dan distribusi ukuran partikel nanoemulsi $\beta$-karoten setelah dipapar fase mulut, lambung dan usus disajikan pada Gambar 2 dan 3.

\section{Ukuran dan Distribusi Ukuran Partikel Droplet}

Nanoemulsi $\beta$-karoten stabil terhadap pencernaan di mulut dan lambung, ditunjukkan dengan diameter partikel rerata yang tidak mengalami perubahan setelah melewati fase mulut dan lambung. Data distribusi ukuran partikel nanoemulsi $\beta$-karoten juga memperlihatkan pola yang sama, yaitu tetap monomodal setelah melewati fase mulut dan lambung, dan berubah menjadi bimodal setelah melewati fase usus. Stabilitas fisik selama melewati fase mulut dan lambung terkait dengan tolakan sterik (steric repulsion) yang dihasilkan oleh gugus hidrofilik netral dari molekul surfaktan nonionik (Qian dkk. 2012a). Sistem penghantaran nanoemulsi pada penelitian ini dibuat menggunakan kombinasi 3 surfaktan nonionik yang sama dan jumlah total surfaktan yang sama, sehingga keduanya memperihatkan stabilitas fisik yang sama terhadap kondisi pencernaan di mulut maupun lambung.

Nanoemulsi $\beta$-karoten tidak stabil terhadap simulasi usus, ditunjukkan oleh terjadinya peningkatan diameter partikel rerata dan perubahan distribusi ukuran partikel dari monomodal menjadi bimodal. Hal ini disebabkan di dalam larutan simulasi usus terdapat molekul berpermukaan aktif seperti ekstrak empedu dan lipase, yang sangat mungkin berkompetisi dengan molekul surfaktan yang berada di lapisan antarmuka nanoemulsi maupun mikroemulsi. Hal tersebut mengakibatkan destabilisasi sistem emulsi seperti koalesensi maupun flukolasi. Lipase merupakan protein berpermukaan aktif yang dapat berkompetisi dengan komponen berpermukaan aktif yang lain di lapisan antarmuka minyak-air (Reis dkk., 2009). Emulsi yang distabilkan oleh surfaktan nonionik mengalami koalesensi dengan keberadaan ekstrak empedu dan lipase pankreas (Mun dkk., 2007). Emulsi yang ditambahkan dengan empedu mengalami peningkatan rerata diameter partikel. Hal tersebut mungkin dikarenakan empedu membentuk lapisan tebal disekitar droplet lipid atau menginduksi terjadinya agregasi droplet lipid (Li dkk., 2011).

\section{Zeta Potensial}

Zeta potensial menggambarkan potensial listrik pada permukaan droplet. Pengukuran Zeta potensial sangat penting untuk pengukuran stabilitas partikel lipid dalam sistem koloid. Stabilitas suspensi koloid atau emulsi dapat diprediksi dan dikendalikan dengan zeta potensialnya. Pengukuran zeta potensial merupakan kunci untuk memahami proses dispersi dan agregasi (Heurtault dkk., 2003).

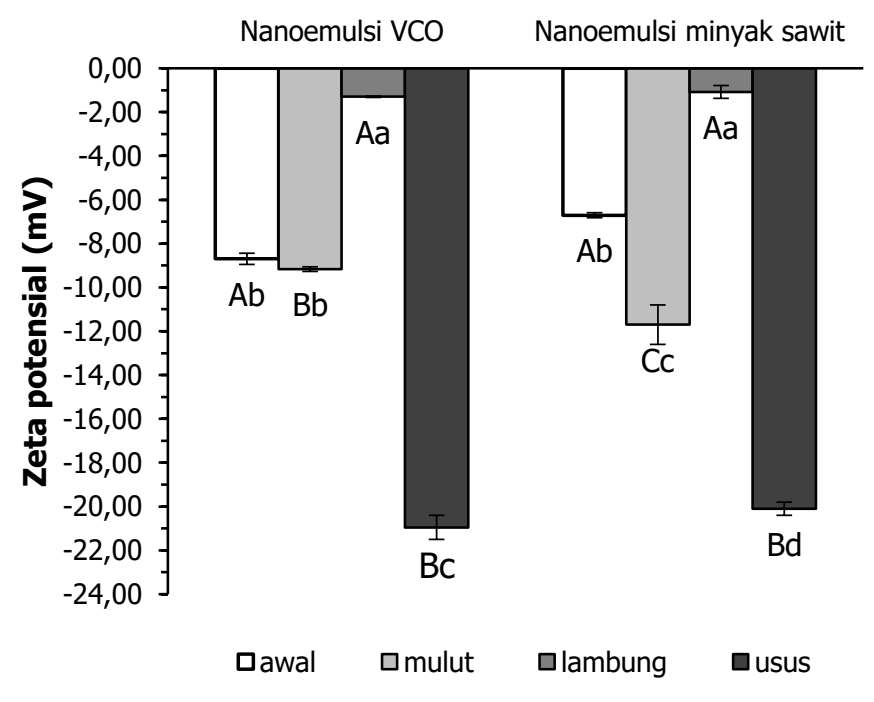

Gambar 4. Muatan listrik partikel nanoemulsi $\beta$-karoten dengan fase minyak yang berbeda, selama simulasi pencernaan. Huruf kapital yang berbeda menunjukkan berbeda nyata $(p<0,05)$ pada fase digesti yang sama, huruf kecil yang berbeda menunjukkan berbeda nyata $(p<0,05)$ pada sistem penghantaran yang sama

Gambar 4 memperlihatkan bahwa nanoemulsi $\beta$ karoten yang diuji mengalami perubahan nilai zeta potensial setelah dipapar kondisi pencernaan di mulut, lambung dan usus. Perubahan muatan listrik droplet selama melewati saluran pencernaan mungkin disebabkan oleh beberapa faktor, seperti perubahan kondisi cairan digesti ( $\mathrm{pH}$ dan kuat ionik), penggantian surfaktan pada lapisan antarmuka droplet oleh komponen yang lebih berpermukaan aktif yang ada dalam cairan digesti, atau adsorpsi bahan yang bermuatan yang ada dalam cairan digesti pada permukaan droplet (Hur dkk., 2009).

Zeta potensial emulsi yang distabilkan oleh surfaktan nonionik dipengaruhi oleh $\mathrm{pH}$. Semakin tinggi $\mathrm{pH}$, nilai zeta potensialnya semakin negatif, dan sebaliknya (Hsu dan Nacu, 2003). pH sistem nanoemulsi $\beta$-karoten awal, setelah melawati fase mulut, lambung dan usus berturut-turut $6,7-6,9 ; 6,7-$ 7,2; 2,0-2,3; dan 6,2-6,4. Oleh sebab pH nanoemulsi setelah dipapar fase lambung terendah dibanding fase digesti yang lain, maka nilai zeta potensialnya juga paling kecil.

Hur dkk. (2009) yang menggunakan model digesti in vitro yang sama dengan penelitian ini menunjukkan muatan droplet emulsi terkecil setelah dipapar fase lambung dan cenderung meningkat setelah dipapar fase usus. Garam empedu yang terdapat dalam cairan simulasi usus merupakan molekul berpermukaan aktif anionik yang mampu menggantikan surfaktan pada lapisan antarmuka droplet (Liu dkk., 2012). Keberadaan empedu dan lipase mengakibatkan peningkatan muatan negatif droplet emulsi dengan nilai zeta potensial yang semakin negatif seiring 
peningkatan konsentrasi lipase pankreas (Sarkar dkk., 2010).

\section{Stabilitas Kimiawi $\beta$-karoten dalam Sistem Penghantaran Nanoemulsi Selama Simulasi Pencernaan in-vitro}

Faktor utama yang membatasi penggabungan $\beta$ karoten pada produk makanan dan minuman adalah kerentanannya yang tinggi terhadap degradasi kimiawi (Piorkowski dan McClements, 2014). Degradasi kimiawi menyebabkan warnanya memudar, dan dapat menurunkan peranannya bagi kesehatan. Panas, cahaya, oksigen singlet, besi, iodine, radikal bebas, enzim, kopel oksidasi dengan lipida dan asam berperan sebagai pemicu degradasi karotenoid (Boon dkk., 2010). Stabilitas kimiawi $\beta$-karoten selama melewati simulasi saluran pencernaan dari sampel nanoemulsi $\beta$-karoten dengan fase minyak VCO dan minyak sawit disajikan pada Gambar 5.

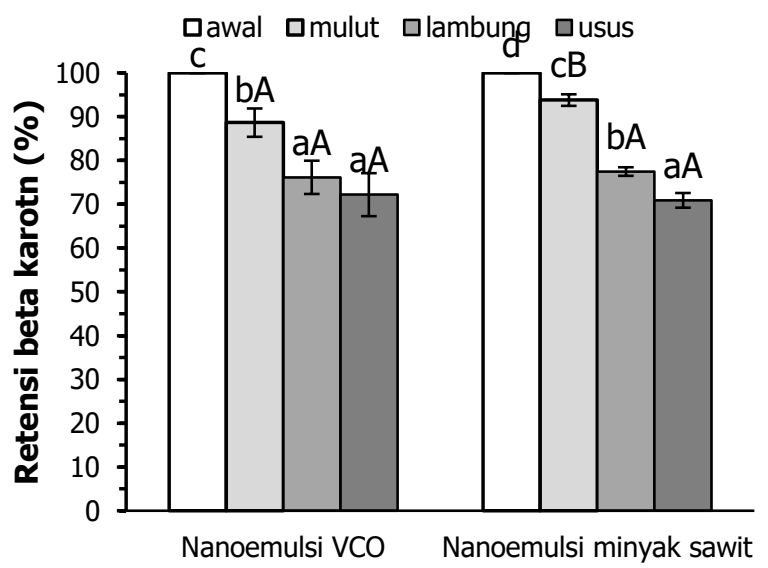

Gambar 5. Stabilitas kimiawi $\beta$-karoten dalam nanoemulsi dengan fase minyak VCO dan minyak sawit, selama simulasi pencernaan. Huruf kapital yang berbeda menunjukkan berbeda nyata $(p<0,05)$ pada fase digesti yang sama, huruf kecil yang berbeda menunjukkan berbeda nyata $(p<0,05)$ pada fase minyak yang sama

$\beta$-karoten dalam nanoemulsi VCO maupun minyak sawit mengalami degradasi setelah dipapar simulasi digesti in-vitro (Gambar 5). Retensi $\beta$-karoten pada fase mulut, lambung dan usus, berturut-turut 88,64 $\pm 3,24 \%$; $76,15 \pm 3,80 \%$ dan $72,19 \pm 4,91 \%$ untuk nanoemulsi VCO, sedangkan untuk nanoemulsi minyak sawit retensinya $93,79 \pm 1,32 \% ; \quad 77,47 \pm 0,98 \%$ dan $70,89 \pm 1,68 \%$. Beberapa penelitian sebelumnya menunjukkan bahwa nanoemulsi (Qian dkk., 2012a) maupun emulsi (Yi dkk., 2014) mampu meningkatkan stabilitas $\beta$-karoten selama digesti in vitro yang ditunjukkan dengan tidak adanya degradasi kimiawi $\beta$-karoten setelah dipapar simulasi saluran pencernaan. Perbedaan hasil ini dimungkinkan karena perbedaan komposisi larutan simulasi digesti, lamanya pemaparan dan analisis stabilitasnya. Pada penelitian ini digunakan komposisi simulasi digesti dan lama pemaparan seperti Versantvoort dkk. (2005) dan (Hur dkk., 2011), kadar $\beta$-karoten ditentukan dengan metode UV-visible spectroscopy (Qian dkk. 2012b). Qian dkk. (2012a) menggunakan komposisi simulasi mulut, lambung dan usus mengikuti Sarkar dkk. (2009), dengan lama pemaparan hampir sama dengan penelitian ini, namun kadar $\beta$-karoten ditentukan dengan menggunakan metode kolorimetrik. Yi dkk. (2014) menggunakan komposisi larutan simulasi digesti mengikuti Garrett dkk. (1999), menggunakan simulasi lambung dan usus masing-masing 1 jam dan 2 jam, dan kadar $\beta$-karoten ditentukan dengan metode HPLC.

Jenis minyak berpengaruh terhadap stabilitas kimiawi $\beta$-karoten dalam nanoemulsi selama simulasi pencernaan di mulut. Nanoemulsi VCO memberikan stabilitas $\beta$-karoten yang signifikan lebih tinggi terhadap pencernaan di mulut dibanding nanoemulsi minyak sawit. Kedua nanoemulsi memperlihatkan degradasi $\beta$-karoten yang sama setelah dipapar pencernaan di lambung dan usus. Hasil ini sejalan dengan stabilitas fisik sistem penghantaran nanoemulsi VCO dan minyak sawit yang tidak berbeda nyata selama simulasi pencernaan di lambung dan usus. Laju degradasi $\beta$-karoten dalam sistem pembawa minyak dalam air (o/w) sangat dipengaruhi oleh stabilitas sistem pembawanya, laju degradasi $\beta$-karoten semakin rendah pada sistem pembawa yang lebih stabil (Cornacchia dan Roos, 2011).

\section{KESIMPULAN}

Nanoemulsi $\beta$-karoten yang dibuat dengan fase minyak VCO maupun minyak sawit menggunakan metode emulsifikasi spontan memiliki pH netral, ukuran partikel yang sangat kecil (129-159 nm), distribusi ukuran partikel monomodal dengan nilai indeks polidispersitas (polydispersity index, PdI) rendah $(0,214-0,266)$ dan zeta potensial yang tidak berbeda nyata $([-6,59]-[-8,9])$. Nanoemulsi $\beta$-karoten dengan fase minyak VCO maupun minyak sawit stabil terhadap pencernaan di mulut dan lambung, namun mengalami destabilisasi setelah melewati fase usus. Nanoemulsi $\beta$ karoten mengalami peningkatan ukuran partikel rerata dan perubahan distribusi ukuran partikel dari monomodal menjadi bimodal. Degradasi $\beta$-karoten dalam sistem penghantaran nanoemulsi VCO selama pencernaan tidak berbeda nyata dengan nanoemulsi minyak sawit.

\section{UCAPAN TERIMA KASIH}

Penelitian ini terselenggara atas dukungan penyediaan dana hibah Riset Fundamental PNBP UNS tahun 2017.

\section{DAFTAR PUSTAKA}

Anton, N., \& Vandamme, T. F. (2011). Nano-emulsions and micro-emulsions: clarifications of the critical differences. Pharmaceutical Research, 28(5), 978-985. http://doi.org/10.1007/s11095-010-0309-1. 
Ariviani, S., Anggrahini, S., Naruki, S., \& Raharjo, S. (2015). Characterization and chemical stability evaluation of $\beta$ carotene microemulsions prepared by spontaneous emulsification method using VCO and palm oil as oil phase. International Food Research Journal, 22(6), 2432-2439.

Bai, S., Lee, S., Na, H., \& Kim, Y. (2005). $\beta$-Carotene inhibits inflammatory gene expression in lipopolysaccharidestimulated macrophages by suppressing redox-based NF- $\mathrm{K}$ B activation. Experimental and Molecular Medicine 37(4), 323-334.

Boon, C. S. (2009). Factor Influencing the Stability of Carotenoids in Oil-in water Emulsions. Dissertation. Departement of Food science, University of Massachusetts Amherst.

Boon, C. S., McClements, D. J., Weiss, J., \& Decker, E. A. (2010). Factors influencing the chemical stability of carotenoids in foods. Critical Reviews in Food Science and Nutrition, 50(6), 515-32. http://doi.org/10.1080/10408390802565889.

Castenmiller, J. J., \& West, C. E. (1998). Bioavailability and bioconversion of carotenoids. Annual Review of Nutrition, 18, 19-38. http://doi.org/10.1146/annurev.nutr.18.1.19.

Cornacchia, L., \& Roos, Y. H. (2011). Stability of $\beta$-carotene in protein-stabilized oil-in-water delivery systems. Journal of Agricultural and Food Chemistry, 59, 7013-7020. http://doi.org//10.1021/jf200841k.

Courraud, J., Berger, J., Cristol, J.-P., \& Avallone, S. (2013). Stability and bioaccessibility of different forms of carotenoids and vitamin A during in vitro digestion. Food Chemistry, 136(2), 871-877. http://doi.org/10.1016/j.foodchem.2012.08.076.

Dayrit, F. M., Buenafe, O. E. M., Chainani, E. T., Vera, I. M. S. De, Dimzon, I. K. D., Gonzales, E. G., \& Santos, J. E. R. (2007). Standards for essential composition and quality factors of commercial virgin coconut oil and its differentiation from rbd coconut oil and copra oil. Philippine Journal of Science, 136(2), 119-129.

Donhowe, E. G., \& Kong, F. (2014). Beta-carotene: Digestion, microencapsulation, and in vitro bioavailability. Journal of Bioprocessing and Technolog, 7, 338-354. http://doi.org/10.1007/s11947-013-1244-z.

Flanagan, J., \& Singh, H. (2006). Microemulsions: a potential delivery system for bioactives in food. Critical Reviews in Food Science and Nutrition, 46(3), 221-237. http://doi.org/10.1080/10408690590956710.

Garrett, D. A., Failla, M. L., Sarama, R. J., \& Craft, N. (1999). Accumulation and retention of micellar $N_{\mathrm{L}}$-carotene and lutein by Caco-2 human intestinal cells. The Journal of Nutritional Biochemistry, 2863(99), 573-581.

Gloria, N. F., Soares, N., Brand, C., Oliveira, F. L., Borojevic, R., \& Teodoro, A. J. (2014). Lycopene and beta-carotene induce cell-cycle arrest and apoptosis in human breast cancer cell lines. Anticancer Research, 34, 1377-1386.

Heurtault, B., Saulnier, P., Pech, B., Proust, J.-E., \& Benoit, J.P. (2003). Physico-chemical stability of colloidal lipid particles. Biomaterials, 24(23), 4283-4300. http://doi.org/10.1016/S0142-9612(03)00331-4.

Hsu, J.-P., \& Nacu, A. (2003). Behavior of soybean oil-in-water emulsion stabilized by nonionic surfactant. Journal of Colloid and Interface Science, 259(2), 374-381. http://doi.org/10.1016/S0021-9797(02)00207-2.

Hur, S. J., Decker, E. A., \& McClements, D. J. (2009). Influence of initial emulsifier type on microstructural changes occurring in emulsified lipids during in vitro digestion. Food Chemistry, 114(1), 253-262. http://doi.org/10.1016/j.foodchem.2008.09.069.
Hur, S. J., Joo, S. T., Lim, B. O., Decker, E. A., \& McClements, J. D. (2011). Impact of salt and lipid type on in vitro digestion of emulsified lipids. Food Chemistry, 126(4), 1559-1564. http://doi.org/10.1016/j.foodchem.2010.12.003.

Kabak, B., \& Ozbey, F. (2012). Assessment of the bioaccessibility of aflatoxins from various food matrices using an in vitro digestion model, and the efficacy of probiotic bacteria in reducing bioaccessibility. Journal of Food Composition and Analysis, 27(1), 21-31. http://doi.org/10.1016/j.jfca.2012.04.006.

Krinsky, N. I., \& Johnson, E. J. (2005). Carotenoid actions and their relation to health and disease. Molecular Aspects of Medicine, 26, 459-516. http://doi.org/10.1016/j.mam.2005.10.001.

Li, Y., Hu, M., \& McClements, D. J. (2011). Factors affecting lipase digestibility of emulsified lipids using an in vitro digestion model: Proposal for a standardised $\mathrm{pH}$-stat method. Food Chemistry, 126(2), 498-505. http://doi.org/10.1016/j.foodchem.2010.11.027.

Liu, Y., Hou, Z., Lei, F., Chang, Y., \& Gao, Y. (2012). Investigation into the bioaccessibility and microstructure changes of $\beta$-carotene emulsions during in vitro digestion. Innovative Food Science dan Emerging Technologies, 15, 86-95. http://doi.org/10.1016/j.ifset.2012.04.002.

Mao, L., Xu, D., Yang, J., Yuan, F., Gao, Y., \& Zhao, J. (2009). Effects of Small and Large Molecule Emulsifiers on the Characteristics of $b$-Carotene Nanoemulsions Prepared by High Pressure Homogenization. Food Technology and Biotechnology, 47(3), 336-342.

Mason, T. G., Wilking, J. N., Meleson, K., Chang, C. B., \& Graves, S. M. (2006). Nanoemulsions: formation, structure, and physical properties. Journal of Physics: Condensed Matter, 18(41), R635-R666. http://doi.org/10.1088/0953-8984/18/41/R01.

McClements, D. J. (2005). Food Emulsions: Principles, Practice, and Techniques (Second Edi). Boca Raton, Florida: CRC Press.

McClements, D. J. (2010). Emulsion design to improve the delivery of functional lipophilic components. Annual Review of Food Science and Technology, 1, 241-69. http://doi.org/10.1146/annurev.food.080708.100722.

McClements, D. J. (2012). Nanoemulsions versus microemulsions: terminology, differences, and similarities. Soft Matter, 8(6), 1719-1729. http://doi.org/10.1039/C2SM06903B.

McClements, D. J., \& Li, Y. (2010). Structured emulsionbased delivery systems: Controlling the digestion and release of lipophilic food components. Advances in Colloid and Interface Science, 159, 213-228. http://doi.org/10.1016/j.cis.2010.06.010.

McClements, D. J., \& Rao, J. (2011). Food-grade nanoemulsions: formulation, fabrication, properties, performance, biological fate, and potential toxicity. Critical Reviews in Food Science and Nutrition, 51(4), 285-330. http://doi.org/10.1080/10408398.2011.559558.

Mu, H., \& Høy, C. (2004). The digestion of dietary triacylglycerols. Progress in Lipid Research, 43(2), 105133. http://doi.org/10.1016/S0163-7827(03)00050-X.

Mun, S., Decker, E. A., \& McClements, D. J. (2007). Influence of emulsifier type on in vitro digestibility of lipid droplets by pancreatic lipase. Food Research International, 40(6), 770-781. http://doi.org/10.1016/j.foodres.2007.01.007.

Mun, S., Kim, Y.-R., \& McClements, D. J. (2015). Control of $\beta$-carotene bioaccessibility using starch-based filled hydrogels. Food Chemistry, 173, 454-461. 
http://doi.org/10.1016/j.foodchem.2014.10.053.

Nik, M. A., Corredig, M., \& Wright, A. J. (2010). Changes in wpi-stabilized emulsion interfacial properties in relation to lipolysis and B-carotene transfer during exposure to simulated gastric-duodenal fluids of variable composition. Food Digestion, 1(1-2), 14-27. http://doi.org/10.1007/s13228-010-0002-1.

Piorkowski, D. T., \& McClements, D. J. (2014). Beverage emulsions: Recent developments in formulation, production, and applications. Food Hydrocolloids 42: 5-41. http://doi.org/10.1016/j.foodhyd.2013.07.009.

Qian, C., Decker, E. A., Xiao, H., \& McClements, D. J. (2012a). Nanoemulsion delivery systems: influence of carrier oil on $\beta$-carotene bioaccessibility. Food Chemistry, 135(3), 14401447. http://doi.org/10.1016/j.foodchem.2012.06.047.

Qian, C., Decker, E. A., Xiao, H., \& McClements, D. J. (2012b). Physical and chemical stability of $\beta$-carotene-enriched nanoemulsions: Influence of $\mathrm{pH}$, ionic strength, temperature, and emulsifier type. Food Chemistry, 132(3), 1221-1229. http://doi.org/10.1016/j.foodchem.2011.11.091.

Ramos, M. J., Fernández, C. M., Casas, A., Rodríguez, L., \& Pérez, A. (2009). Influence of fatty acid composition of raw materials on biodiesel properties. Bioresource Technology, 100(1),

261-8. http://doi.org/10.1016/j.biortech.2008.06.039.

Rao, J., \& McClements, D. J. (2011). Formation of flavor oil microemulsions, nanoemulsions and emulsions: influence of composition and preparation method. Journal of Agricultural and Food Chemistry, 59(9), 5026-35. http://doi.org/10.1021/jf200094m.

Reis, P., Miller, R., Leser, M., \& Watzke, H. (2009). Lipasecatalyzed reactions at interfaces of two-phase systems and microemulsions. Applied Biochemistry and Biotechnology, 158(3), 706-21. http://doi.org/10.1007/s12010-008-83545.

Rodriguez-Amaya, D. B., Kimura, M., Godoy, H. T., \& AmayaFarfan, J. (2008). Updated Brazilian database on food carotenoids: Factors affecting carotenoid composition. Journal of Food Composition and Analysis, 21(6), 445-463. http://doi.org/10.1016/j.jfca.2008.04.001.

Salvia-Trujillo, L., Qian, C., Martín-Belloso, O., \& McClement, D. J. (2013). Influence of particle size on lipid digestion and $\beta$-carotene bioaccessibility in emulsions and nanoemulsions. Food Chemistry, 141(2), 1472-80. http://doi.org/10.1016/j.foodchem.2013.03.050.

Salvia-Trujillo, L., Qian, C., Martín-Belloso, O., \& McClements, D. J. (2013). Modulating $\beta$-carotene bioaccessibility by controlling oil composition and concentration in edible nanoemulsions. Food Chemistry, 139(1-4), 878-884. http://doi.org/10.1016/j.foodchem.2013.02.024.

Salvia-Trujillo, L., Rojas-Graü, A., Soliva-Fortuny, R., \& MartínBelloso, O. (2013a). Physicochemical characterization of lemongrass essential oil-alginate nanoemulsions: Effect of ultrasound processing parameters. Food and Bioprocess Technology, 6(9), 2439-2446. http://doi.org/10.1007/s11947-012-0881-y.

Salvia-Trujillo, L., Rojas-Graü, M. A., Soliva-Fortuny, R., \& Martín-Belloso, O. (2013b). Effect of processing parameters on physicochemical characteristics of microfluidized lemongrass essential oil-alginate nanoemulsions. Food Hydrocolloids, 30(1), 401-407. http://doi.org/10.1016/j.foodhyd.2012.07.004.

Sarkar, A., Goh, K. K. T., \& Singh, H. (2009). Colloidal stability and interactions of milk-protein-stabilized emulsions in an artificial saliva. Food Hydrocolloids, 23(5), 1270-1278. http://doi.org/10.1016/j.foodhyd.2008.09.008.

Sarkar, A., Horne, D. S., \& Singh, H. (2010). Pancreatininduced coalescence of oil-in-water emulsions in an in vitro duodenal model. International Dairy Journal, 20(9), 589-597. http://doi.org/10.1016/j.idairyj.2009.12.007.

Stefanovich, A. F., \& Karel, M. (1982). Kinetics of betacarotene degradation at temperatures typical of air drying of foods. Journal of Food Processing and Preservation, 6(4), 227-242

Tan, C. P., \& Nakajima, M. (2005). Food Chemistry b carotene nanodispersions: preparation, characterization and stability evaluation. Food Chemistry, 92, 661-671. http://doi.org/10.1016/j.foodchem.2004.08.044.

Versantvoort, C. H. M., Oomen, A. G., Van de Kamp, E., Rompelberg, C. J. M., \& Sips, A. J. A. M. (2005). Applicability of an in vitro digestion model in assessing the bioaccessibility of mycotoxins from food. Food and Chemical Toxicology, 43(1), 31-40. http://doi.org/10.1016/j.fct.2004.08.007.

Xu, D., Wang, X., Jiang, J., Yuan, F., Decker, E. A., \& Gao, Y. (2013). Influence of $\mathrm{pH}, \mathrm{EDTA}$, a-tocopherol, and WPI oxidation on the degradation of $\beta$-carotene in WPIstabilized oil-in-water emulsions. $L W T$ - Food Science and Technology, 54(1), http://doi.org/10.1016/j.lwt.2013.05.029.

Yang, Y., Marshall-Breton, C., Leser, M. E., Sher, A. A., \& McClements, D. J. (2012). Fabrication of ultrafine edible emulsions: Comparison of high-energy and low-energy homogenization methods. Food Hydrocolloids, 29, 398406. http://doi.org/10.1016/j.foodhyd.2012.04.009.

Yang, Y., \& McClements, D. J. (2013). Vitamin E bioaccessibility: influence of carrier oil type on digestion and release of emulsified a-tocopherol acetate. Food Chemistry, 141(1), 473-81. http://doi.org/10.1016/j.foodchem.2013.03.033.

Yi, J., Li, Y., Zhong, F., dan Yokoyama, W. (2014). The physicochemical stability and in vitro bioaccessibility of beta-carotene in oil-in-water sodium caseinate emulsions. Food Hydrocolloids, 35, 19-27. http://doi.org/10.1016/j.foodhyd.2013.07.025.

Yuan, Y., Gao, Y., Zhao, J., \& Mao, L. (2008). Characterization and stability evaluation of $\beta$-carotene nanoemulsions prepared by high pressure homogenization under various emulsifying conditions. Food Research International, 41(1), 61-68. http://doi.org/10.1016/j.foodres.2007.09.006. 